\title{
ABO Blood Type and Pediatric Acute Respiratory Distress Syndrome
}

\section{ABO Kan Tipi ve Çocuk Akut Solunum Sıkıntısı Sendromu}

\author{
(1) Sema Yılmaz¹, (1) Özden Özgür Horoz², (1) Gizem Güngör³, (1) Dinçer Yıldızdaş2 \\ 1 Uşak University Faculty of Medicine, Department of Pediatric Hematology and Oncology, Uşak, Turkey \\ ${ }^{2}$ Çukurova University Faculty of Medicine, Department of Pediatric Intensive Care Unit, Adana, Turkey \\ 3University of Health Sciences Turkey, Kanuni Training and Research Hospital, Clinic of Pediatrics, Istanbul, Turkey
}

Keywords: $A B O$ blood type, acute, child, respiratory distress

Anahtar Kelimeler: ABO kan tipi, akut, çocuk, solunum sıkıntısı

\section{To the Editor,}

Pediatric acute respiratory distress syndrome (PARDS) is an acute-onset and progressive hypoxic condition caused by direct injury to the lung (e.g., pneumonia and gastric aspiration) or indirect injury (e.g., sepsis, trauma and pancreatitis). ${ }^{1}$ Blood types were discovered in the early 1900s, and blood type system based on the presence or absence of specific antigens on the surface of red blood cells (RBC). ${ }^{2}$ The antigens of the $A B O$ blood group system (referred to as $A, B$, and $H$ ) are complex carbohydrate molecules located on the erythrocyte cell surface. They are also highly expressed on the surface of various human cells and tissues including the epithelium, sensory neurons, platelets, and vascular endothelium. Several previous studies have shown that blood group antigens are closely related to infectious diseases, vascular diseases, autoimmune diseases, malignant tumors, and other diseases. ${ }^{3,4}$

Blood type $A$ has been associated with increased risk of endothelial inşammation. Previous studies noticed that the a glycosyltransferase phenotype is associated with an increased risk of myocardial infarction and thrombotic events..$^{5,6}$ In blood type A phenotype, the polymorphisms of glycosyltransferase may lead to increased risk of vascular diseases. These effects of $A B O$ glycosyltransferase activity on von Willebrand factor structure have been hypothesized in order to explain the association between $A B O$ blood type and vascular diseases. ${ }^{7}$ It is not clear the relationship between the activity of the $A B O$ glycosyltransferases and the development of ARDS. In one study, blood type A was found to be associated with increased risk of ARDS in critically ill patients with trauma and sepsis. ${ }^{8}$

We investigated total of 22 children (aged 1 month to 18 years old) diagnosed with PARDS and 11 of non-ARDS cases. Patients were fulfilled the Pediatric Acute Lung Injury Consensus Conference definition for PARDS and intubated. While pneumonia (13 of 22 patients, 59.0\%) was the most common pulmonary reason of PARDS, aspiration was seen in that of $3(13.6 \%)$ cases. Trauma and sepsis were recorded in that of one $(4.6 \%)$, and $5(22.8 \%)$ patients, respectively as extrapulmonary causes. ABO blood type was determined by standard RBC typing performed for clinical purposes before the receipt of transfused blood products. The $A B O$ blood type was collected from blood bank records, allowing patients to be classifed as blood type $A, B, A B$, and $O$. Blood type $A, B, A B$, and $O$ were detected in $12,5,1$ and 4 patients with ARDS, respectively. The degree of hypoxemia was noted as 2 mild, 5 moderate and 5 severe hypoxemia in PARDS children with blood type A. In our study, some variables, such as pneumonia

Yazışma Adresi/Address for Correspondence: Sema Yılmaz, Uşak University Faculty of Medicine, Department of Pediatric Hematology and Oncology, Uşak,

Turkey E-posta: semayilmaz@hotmail.com ORCID ID: orcid.org/0000-0003-4277-3880

Geliş Tarihi/Received: 17.04.2020 Kabul Tarihi/Accepted: 13.05 .2020

- Copyright 2021 by Society of Pediatric Emergency and Intensive Care Medicine

Journal of Pediatric Emergency and Pediatric Intensive Care published by Galenos Yayınevi. 
was mostly seen 8 (36.3\%) of patients who had A blood type and showed $75 \%$ infiltration area of lung.

In the present study, we hypothesized that blood type A was associated with increased risk of ARDS in critically ill children. The potential mediators may directly or indirectly have an effect of $A B O$ blood type on ARDS. The relationship between $A B O$ blood type and pathogenesis of ARDS should be analyzed before these results are accepted into clinical practice. Future studies are needed to explore the main role of blood type A in mediating ARDS risk.

\section{Ethics}

Peer-review: Internally peer-reviewed.

\section{Authorship Contributions}

Concept: S.Y., Design: S.Y., Data Collection or Processing: S.Y., Ö.Ö.H., G.G., D.Y., Analysis or Interpretation: S.Y., D.Y., Literature Search: S.Y., Writing: S.Y.

Conflict of Interest: No conflict of interest was declared by the authors.

Financial Disclosure: The authors declared that this study received no financial support.

\section{References}

1. Baron RM, Levy BD. Recent advances in understanding and treating ARDS. F1000Res. 2016;5:F1000 Faculty Rev-725.

2. Ewald DR, Sumner SC. Blood type biochemistry and human disease. Wiley Interdiscip Rev Syst Biol Med. 2016;8:517-35.

3. Liumbruno GM, Franchini M. Beyond immunohaematology: the role of the $A B O$ blood group in human diseases. Blood Transfus. 2013;11:491-9.

4. Czerwiński M. Grupy krwi-minusy i plusy. Czy antygeny grupowe krwi chronią nas przed chorobami zakaźnymi? [Blood groups - minuses and pluses. Do the blood group antigens protect us from infectious diseases?]. Postepy Hig Med Dosw (Online). 2015:69:703-22.

5. Wiggins KL, Smith NL, Glazer NL, Rosendaal FR, Heckbert SR, et al. $A B O$ genotype and risk of thrombotic events and hemorrhagic stroke. J Thromb Haemost. 2009;7:263-9.

6. He M, Wolpin B, Rexrode K, Manson JE, Rimm E, et al. ABO blood group and risk of coronary heart disease in two prospective cohort studies. Arterioscler Thromb Vasc Biol. 2012;32:2314-20.

7. Wu O, Bayoumi $\mathrm{N}$, Vickers $\mathrm{MA}$, Clark $\mathrm{P} . \mathrm{ABO}(\mathrm{H})$ blood groups and vascular disease: a systematic review and meta-analysis. J Thromb Haemost. 2008;6:62-9.

8. Reilly JP, Meyer NJ, Shashaty MGS, Feng R, Lanken PN, et al. $A B O$ blood type $A$ is associated with increased risk of ARDS in whites following both major trauma and severe sepsis. Chest. 2014; 145:753-61. 